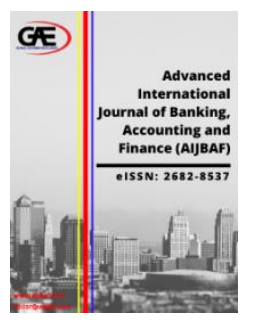

\author{
ADVANCED INTERNATIONAL JOURNAL OF \\ BANKING, ACCOUNTING AND FINANCE \\ (AIJBAF) \\ www.aijbaf.com
}

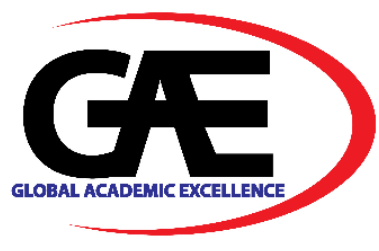

\title{
A STUDY ON THE RELATIONSHIP BETWEEN ATTITUDE AND TAX COMPLIANCE: A CASE STUDY OF CIVIL SERVANTS IN SELANGOR
}

Noorliana Safian ${ }^{1 *}$, Nor Syamaliah $\mathrm{Ngah}^{2}$

1 Faculty of Administrative Science \& Policy Studies, Universiti Teknologi Mara, Malaysia

Email: noorliana_safian@uitm.edu.my

2 Faculty of Administrative Science \& Policy Studies, Universiti Teknologi Mara, Malaysia

Email: syamaliah@uitm.edu.my

* Corresponding Author

\section{Article Info:}

Article history:

Received date:06.10.2020

Revised date: 15.10 .2020

Accepted date: 18.11.2020

Published date: 01.12.2020

To cite this document:

Safian, N., \& Ngah, N. S. (2020). A Study on The Relationship between Attitude and Tax Compliance: A Case Study of Civil Servants in Selangor. Advanced International Journal of Banking, Accounting, and Finance, 2 (5), 45-54.

DOI: $10.35631 / A I J B A F .25004$.

This work is licensed under $\mathrm{CC} B \mathrm{BY} 4.0$

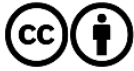

\section{Abstract:}

Tax compliance has not been easy for any government across the globe. The numbers of eligible taxpayers did not comply with their tax obligations annually. There are a number of past researches that prove the association of attitude towards tax compliance behaviour. Having said that, this study interested in examines the influence of taxpayers' attitudes towards their tax compliance behaviour. This quantitative research uses a self-administered questionnaire as its medium of data collection. There are 120 civil servants in Selangor who participated as respondents. The findings of the data revealed a moderate relationship between attitude and tax compliance behaviour.

Keywords:

Attitude, Tax Compliance, Civil Servants

\section{Introduction}

Tax compliance, or lack of, taxes has been a common topic of public policy throughout history. While being a global issue and a phenomenon that has existed for decades, there is relatively recent attention to the subject as a research area for both tax non-compliance and tax evasion. 
Volume 2 Issue 5 (December 2020) PP. 45-54 DOI 10.35631/AIJBAF.25004

Although a large amount of information about tax compliance actions has been acquired in a short time, there is still more to be learned on the subject, as the tax non-compliance problem is deteriorating rather than improving. Historically, tax policy literature focused on the effect of economic conditions on taxpayer behaviour. The belief that people are going to behave in their own best interests is the foundation of the utility model they expect. Allingham and Sandmo (1972) proposed this model as an explanation for conduct about tax compliance behaviour.

Worldwide studies have pointed out that tax compliance rates are low in high-income countries and lower even in medium- and low-income countries. Survey of compliance behaviour have been conducted about fairness perceptions and compliance behaviour: taxpayers ${ }^{\text {ee judgments }}$ in self-assessment environments (Saad, 2011).

In Malaysian context, $56 \%$ of the total federal government revenue came from taxes, in which $40.3 \%$ came from income tax. As from the whole tax cake portion, income taxes is the highest contributor followed by companies taxes and petroleum taxes (Refer Figure 1.1). Realizing the importance of tax as a vital source of income, the Government through the Inland Revenue Board (IRB) continuously intensified their efforts to accomplish high tax collection. The amount proves succeeded when the amount of income tax collection showed a gradual increment as indicated. It increases in difference at 7.76\% in 2016-2017 from 4.69\% in 20152016 (Inland Revenue Board of Malaysia, 2019).

It is important to note that from the number of taxpayer recorded, there are large number of cases finalized following the tax investigation conducted by IRB which signal that, this could be an indicator of the efficiency of the IRB in conducting the tax audit at the same time it could also reflect the number of non-compliant tax payer in Malaysia. To better comprehend the Malaysian tax scenario, it is worthwhile to compare it with other neighbouring countries as well OECD average. Figure 1.2 illustrated tax to GDP ratios among Asia countries. Although Malaysia remarks a better position from Indonesia and Singapore, but Malaysia's point below Japan and Korea as well as OECD average. Compared to Philippines and Singapore who experienced increased in their tax to GDP ratio between 2013 and 2014, Malaysia experienced decreases (OECD Data, 2018). This scenario continues until 2015, where tax to GDP ratio noted reductions.

Figure 1.1: Comparison of Direct Tax Collection by Component

\begin{tabular}{|c|c|c|c|}
\hline Direct Tax Component & $\begin{array}{l}2017 \\
\text { [RM Million] }\end{array}$ & [RM ${ }^{2016}$ Mitlion] & $\begin{array}{c}\text { Difference } \\
{[\%]}\end{array}$ \\
\hline Individuals & $31,901.57$ & 29.603 .47 & 7.76 \\
\hline Companies & $68,801.94$ & $65,974.74$ & 4.29 \\
\hline Stamp Duty & 5.670 .32 & 5.674 .04 & {$[0.07]$} \\
\hline Withholding Tax & $3,266.38$ & $2,549.36$ & 28.13 \\
\hline RPGT & 1.697 .98 & 1.491 .67 & 13.83 \\
\hline Cooperatives & 74.48 & 89.71 & {$[16.98]$} \\
\hline Other Taxes & 86.69 & 90.09 & [3.77] \\
\hline Other IT - Sec 124 & 51.23 & 46.18 & 10.94 \\
\hline Petroleum & $11,760.92$ & 8.425 .76 & 39.58 \\
\hline Gross Collection & $123,311.51$ & $113,945.02$ & 8.22 \\
\hline
\end{tabular}

Source: Lembaga Hasil Dalam Negeri (2017) 
In Malaysian context, tax evasion is a severe offence chargeable under Section 114 of the Income Tax Act which includes offences like (a) omits from a return made under the Act any income which should be included, (b) make a false statement in a return, (c) gives a false answer (orally or in writing) to a question asked or request for information made in pursuance of the Act, (d) prepares or maintains or authorizes the preparation or maintenance of false books of account or other false records, (e) falsifies or authorizes the falsification of books of account or other records; or (f) makes use or authorizes the use of any fraud, art or contrivance. Therefore, it can be concluded here that, tax compliance is an act of complying with rules and regulations as specified in the Income Tax Act 1967 (with amendment). This includes, filing tax return, reporting all income and expenses accurately, paying all amount of taxes owed and fulfilling all the deadlines provided by the tax authority.

Therefore, with the rising trend of non-compliance among the taxpayers, the present study aims to explore the factors which could influence people to comply with the tax law in order to better understand the behavior of the taxpayers. Appropriate mechanism could be used to increase the level of voluntary compliance especially among the civil servants who served as the backbone of the government.

Figure 1.2: Tax Structures (\% Of Total Tax Revenue), 2017 In Asian Pacific

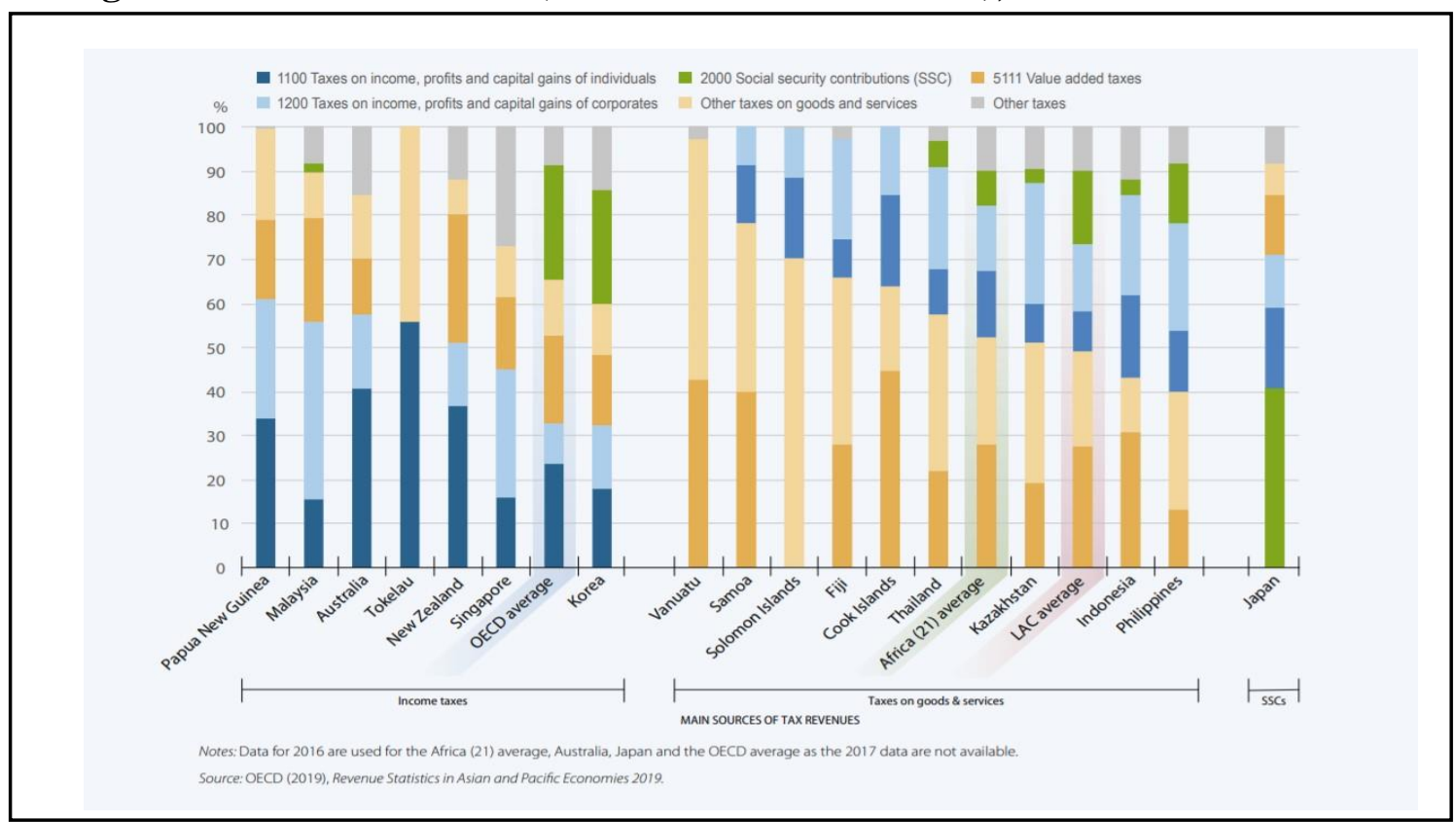

Source: OECD (2017)

\section{Literature Review}

\section{Tax Compliance Behaviour}

Tax compliance behaviour is a complex subject (James and Alley, 2002). It is not possible to understand this behaviour through a single factor (McKerchar, 2010). A number of previous research for example Saad (2011) and Abdul Hamid (2014) was undertaken to understand the compliance behaviour through Theory of Planned Behaviour (Ajzen, 1991) framework. This 


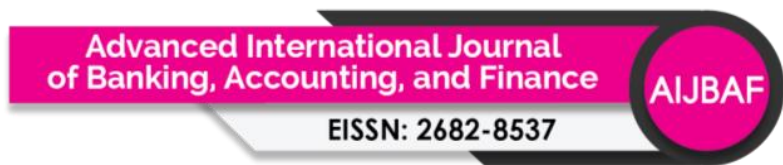

Volume 2 Issue 5 (December 2020) PP. 45-54 DOI 10.35631/AIJBAF.25004

study aims to follow the same path by focusing on one of the Theory of Pland Behaviour (TPB) variable which is attitude. This variable is then tested to civil servants in Selangor in order to better understand the attitude of civil servants with respect to complying with the tax law.

Vast number of researches have been devoted in understanding tax compliance behaviour cutting across various disciplines such as accounting, economics, political science, public administration and psychology. Various factors lead to tax compliance behaviour has been revealed from the research. For instance, the Inland Revenue Service of US listed as many as 64 factors that affect taxpayers reporting decision (Alm, 1999). Some of the factors include, demographic factors (See for example, Aitken and Bonneville, 1980; Chan et al., 2000; Chen, 2006; Hamzah Sendut, 1991, Hasseldine and Hite, 2003; Hite, 1997; Jackson, 1986; Jeyapalan Kassipilai et al., 2003; Richardson, 2006; Song and Yarbrough, 1978), economics factors (See for example, Allingham and Sandmo, 1972; Alm and Jackson, 1992; Clotfelter, 1983; Davis et al., 2003; Friedland et al., 1978; Kirchler et al., 2008; Park and Hyun, 2003; Pommerehne and Weck-Hannemann, 1996; Srinivasan, 1973) and behavioural factors (Chan et al., 2000; Orviska and Hudson, 2003; Viswanath Umashanker Trivedi et al., 2003). Furthermore, Jackson, (1986) in their comprehensive review studies highlighted 14 variables that were most commonly examined in tax compliance literature. Richardson and Sawyer (2001) then updated this synthesis by adding up another five variables.

Generally, previous tax compliance studies debated the issues of tax compliance by using either economic approach or socio-psychological approach (Alm et al.,1995; Andreoni et al., 1998; James and Alley, 2002). While economic approach focuses on tax gap, psychological approach on the other hand, stresses on the importance of voluntary compliance. The concentration of economic approach is only on the trade-off between benefits of evading and the risk of detection. This is in contrast from the psychological approach which in the premise that compliance behaviour is constructed by various factors and not focuses on economic factor solely. The characteristics between the two approaches are illustrated in the following Table 1.1 .

\section{Theory of Planned Behaviour (TPB)}

Socio-Psychological proponents argued that the understanding on compliance goes beyond the deterrence factor as described in the economic model. As posited by Feld and Frey (2007), tax compliance is a psychological tax contract that goes beyond traditional deterrence and explains tax morale as a complicated interaction between taxpayers and the government. The past decade has observed the rapid development on the study on socio-psychological factors in understanding tax compliance behaviour as discussed in the previous section. Psychological aspects like knowledge (Andreas Enni Savitri, 2015; Mei L. et al. 2012; Natrah Saad, 2014), fairness (Abdulhadi Khasawneh et al. 2008; Natrah Saad, 2011), social norms (Bobek and Hageman, 2015), religion (Raihana Mohd Ali, 2013) and many other factors were examined against tax compliance behaviour. Apart from all these factors, there are also some researcher who tested behavioural theories such as TPB (Ajzen, 1991), Goal-Framing Theory (Lindenberg, 2001) and Equity Theory (Adams, 1963) in predicting taxpayers compliance behaviour. But, the most influential behavioural theories used in tax compliance research is TPB.

Number of few studies had attempted to test TPB in the context of tax compliance. For example in Bobek and Hageman (2015) and Viswanath Umashanker Trivedi, Mohamed Shehata and Copyright (C) GLOBAL ACADEMIC EXCELLENCE (M) SDN BHD - All rights reserved 
Volume 2 Issue 5 (December 2020) PP. 45-54 DOI 10.35631/AIJBAF.25004

Mestelman (2004) it is confirmed that the TPB is effective in explaining compliance behaviour. The measure of compliance is found to have a high correlation with actual tax evasion behaviour. The TPB also has been used to analyze the compliance behaviour of the Malaysian's taxpayers (For example, Natrah Saad, 2010) and Malaysian tax agents (For example, Suhaila Abdul Hamid, 2014). It is proven that TPB is capable in explaining the tax compliance behaviour in Malaysia where two of its components are found to be highly influential to tax compliance behaviour.

Despite of being widely used, the TPB has some limitations. First, behaviour is a complex issue. To understand behaviour only by looking at attitudes, subjective norms and perceived behavioural control is not sufficient. There are some other determinants that might influence behaviour. Second, there may be a substantial gap of time between assessment of behaviour intention and the actual behaviour being assessed (Werner, 2005). During the time gap, the intention of an individual might change.

Table 1.1 Economic verses Psychology Approaches in Tax Compliance Studies

\begin{tabular}{|c|c|c|}
\hline Tax Compliance & Economic Approach & Psychology Approach \\
\hline Concept & $\begin{array}{l}\text { Tax Gap } 100 \% \text { compliance } \\
\text { less actual revenue }\end{array}$ & $\begin{array}{l}\text { Voluntary. Willingness to act } \\
\text { in accordance with the spirit } \\
\text { as well as the letter of the law }\end{array}$ \\
\hline Tax compliance & Economic Rationality & Behavioural cooperation \\
\hline Definition & Narrower & Wider \\
\hline Exemplified by & $\begin{array}{l}\text { Trade Off: 1. Expected } \\
\text { benefits of evading } \\
\text { 2. Risk of } \\
\text { detection and application of } \\
\text { penalties 3. } \\
\text { personal wealth }\end{array}$ & $\begin{array}{l}\text { Individuals are not simply } \\
\text { independent, selfish utility } \\
\text { maximizers. They interact } \\
\text { according to differing } \\
\text { attitudes, beliefs, norms and } \\
\text { roles. Success depends on } \\
\text { co-operation }\end{array}$ \\
\hline Issues of & $\begin{array}{l}\text { Efficiency in resource } \\
\text { allocation }\end{array}$ & $\begin{array}{l}\text { Equity, fairness and } \\
\text { incidence }\end{array}$ \\
\hline Taxpayer seen as & $\begin{array}{l}\text { Selfish calculator of } \\
\text { pecuniary gains and losses }\end{array}$ & "Good citizen" \\
\hline Can be termed the & Economic Approach & Behavioural Approach \\
\hline
\end{tabular}

Source: James and Alley, 2002 (pg 33)

\section{The Influence of Attitude towards Tax Compliance}

One of the important elements in TPB framework is attitude. Attitude is directly related to behaviour to the degree it is influenced by the intention (Armitage \& Christian, 2003). In many tax compliances studies, Kirchler (2007) found, that while the relationships between attitude towards tax compliance and behaviour indicate weak relationships, these are significant.

In understanding the influence of attitude towards tax compliance, number of studies have analyse its relationship, for example in Eriksen and Fallan (1996) examine two different groups of students from marketing and law. They suggest that tax attitude is important in determining tax compliance behaviour and this tax attitude is influenced by the specific tax knowledge that the students possess. This is consistent with Hanno \& Violette, (1996) who experientially prove Copyright @ GLOBAL ACADEMIC EXCELLENCE (M) SDN BHD - All rights reserved 


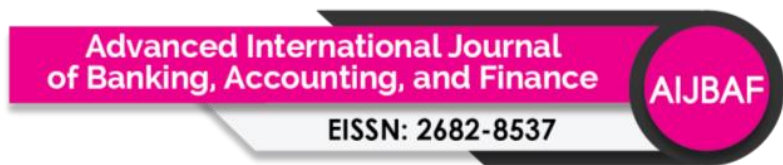

Volume 2 Issue 5 (December 2020) PP. 45-54 DOI 10.35631/AIJBAF.25004

the positive link between attitude towards tax compliance and compliance behaviour. Using the TRA the authors handled an experimental design among 73 College students who have experience in filing tax returns. In another study of Trivedi, Shehata and Mestelman (2005) which utilize the TPB model to better understand tax compliance behaviour, employs both survey and experimental design among the University students and it was found out that, attitude has significant impact to taxpayers' decision making. The attitude of taxpayers is also studied by Chan et al. (2000) comparing US and Hong Kong taxpayers. The study suggest that the attitude of taxpayers is dependent on the degree of moral reasoning that the taxpayers have. US taxpayers is said to have higher moral reasoning which indicates better attitude towards complying with the tax law.

Zooming into Malaysian context, Kassipilai and Jabbar (2003) prove that, attitude towards tax compliance was empirically significant. In a study by Saad (2011) using individual taxpayers in Malaysia and New Zealand, her findings suggest that taxpayers in both countries considered attitude as an important factor in complying with the tax law. This is consistent with the findings of Abdul Hamid (2013) who analyse attitude towards tax compliance among the tax agents, found out that, attitude is a significant variable towards understanding the tax agents compliance behaviour.

\section{Methodology}

The present study used quantitative approach as its methodology. As define by Cohen et al., (2007), quantitative research is well-defined as social research that make use of empirical methods and empirical statements. He then furthers states that empirical statement is based on a descriptive statement regarding what is the real world is rather than what real world is ought to. The existing study adopted quantitative as its research methodology because quantitative method is the finest method that can be used in explaining a phenomenon. It is a terrific method to further describe what create a phenomenon, what are the factors that lead to a phenomenon. As the current research interested in understanding a tax compliance phenomenon, and the researcher target to inquire into whether attitude does have influences towards tax compliance behaviour. Therefore, quantitative design is the best as it suits the purpose.

This study involves understanding on the tax compliance among the civil servants. Civil servant can be defined as Public Service formerly known as the Civil Service has assumed a significant key role in the economic and social development of the country. According to Federal Constitution Act 132 (1) civil servant are among the (a)armed forces, (b)judicial and legal service, (c)general public service of the Federation, (d)police force, public service of each state, education service, (f)joint services. Person who is a member of any of the services mentioned in paragraphs (a), (b), (c), (d), (f) and $€$ of Clause (1) holds office during the pleasure of the Yang di-Pertuan Agong, and, except as expressly provided by the Constitution of the State, every person who is a member of the public service of a State holds office during the pleasure of the Ruler or Yang di-Pertua Negeri (Attorney General's Chambers of Malaysia, 2019). Which means, civil servant needs to practice good ethics in perform their task and follow the rule and regulation that been set by government. For example, civil servant needs practice trust, integrity, responsibility, excellence, loyalty, commitment, dedication, discipline, diligence and professionalism (Prime Minister's Office of Malaysia, 2019).

The population of this study is derived from the database developed by the researcher where Table 1.3 shown that active employers in Negeri Selangor have active employees Copyright $\odot$ GLOBAL ACADEMIC EXCELLENCE (M) SDN BHD - All rights reserved 
approximately around 1,921,904 in 2018. So, this study will be targeted Selangor civil servants as respondent. This is because it shown Selangor state have the largest amount number of active employees compares to W.P Kuala Lumpur. To determine sample size Krejcie and Morgan (1970) table of sample size is bring forth below. Based on the author, as the population increases at $170 \mathrm{~N}$, the sample increase at diminishing rate and the sample size remain constant at slightly at $118 \mathrm{~S}$. On the other hand, Sekaran and Bougie (2011) also suggested that the common sample size of many studies is within the range of 30 to 500 samples.

\section{Table 1.3: Number of Active Employers and Active Employees 2014 - 2018 by State and Channel Environment}

\begin{tabular}{|c|c|c|c|c|c|c|c|c|c|c|}
\hline \multirow{2}{*}{ Negeri } & \multicolumn{5}{|c|}{ Majikan Aktif } & \multicolumn{5}{|c|}{ Pekerja Aktif } \\
\hline & 2014 & 2015 & 2016 & 2017 & 2018 & 2014 & 2015 & 2016 & 2017 & 2018 \\
\hline Johor & 53,101 & 55,347 & 57,302 & 58,394 & 59,507 & 652,185 & 684,897 & 699,318 & 734,183 & 764,537 \\
\hline Kedah & 17,080 & 17,364 & 17,845 & 17,738 & 17,569 & 230,313 & 235,233 & 243,838 & 245,251 & 258,044 \\
\hline Kelantan & 8,048 & 8,021 & 8,014 & 7,984 & 7,965 & 86,868 & 88,676 & 89,464 & 89,572 & 94,072 \\
\hline Melaka & 12,726 & 12,907 & 13,212 & 13,213 & 13,243 & 164,100 & 172,707 & 192,361 & 199,199 & 189,285 \\
\hline Negeri Sembilan & 12,602 & 12,794 & 13,169 & 13,250 & 13,427 & 153,115 & 158,080 & 159,718 & 164,629 & 174,982 \\
\hline Pahang & 15,383 & 15,672 & 16,072 & 16,157 & 15,906 & 173,442 & 167,909 & 169,644 & 174,017 & 180,127 \\
\hline Perak & 30,798 & 31,141 & 32,036 & 32,245 & 31,993 & 312,515 & 319,922 & 327,018 & 338,379 & 343,523 \\
\hline Perlis & 1,900 & 1,928 & 2,015 & 1,962 & 1,931 & 21,494 & 21,555 & 21,663 & 20,222 & 21,578 \\
\hline Pulau Pinang & 29,452 & 30,365 & 31,027 & 31,254 & 31,430 & 458,907 & 476,349 & 495,206 & 517,853 & 534,425 \\
\hline Sabah & 29,752 & 29,892 & 30,274 & 30,114 & 29,600 & 332,096 & 342,542 & 344,529 & 348,265 & 361,803 \\
\hline Sarawak & 34,208 & 35,570 & 36,860 & 37,278 & 37,359 & 446,746 & 464,678 & 470,694 & 484,114 & 494,825 \\
\hline Selangor & 86,821 & 91,059 & 95,318 & 98,060 & 100,867 & $1,555,697$ & $1,606,408$ & $1,696,430$ & $1,763,733$ & $1,921,908$ \\
\hline Terengganu & 8,478 & 8,616 & 8,501 & 8,441 & 8,360 & 117,360 & 116,524 & 116,645 & 155,148 & 127,881 \\
\hline W.P Kuala Lumpur & 61,690 & 63,588 & 66,045 & 67,633 & 67,903 & $1,493,819$ & $1,521,504$ & $1,571,330$ & $1,609,383$ & $1,610,441$ \\
\hline \multirow{2}{*}{ Lingkungan gaji } & \multicolumn{5}{|c|}{ Majikan Aktif } & \multicolumn{5}{|c|}{ Pekerja Aktif } \\
\hline & 2014 & 2015 & 2016 & 2017 & 2018 & 2014 & 2015 & 2016 & 2017 & 2018 \\
\hline Bawah/Below 100 & 393,970 & 406,448 & 419,059 & 424,997 & 427,771 & $3,190,715$ & $3,402,791$ & $3,382,734$ & $3,491,553$ & $3,597,441$ \\
\hline $100-199$ & 4,496 & 4,642 & 4,762 & 4,853 & 5,093 & 616,518 & 637,231 & 656,023 & 688,016 & 702,226 \\
\hline $200-299$ & 1,371 & 1,400 & 1,494 & 1,498 & 1,662 & 330,280 & 338,436 & 361,634 & 371,739 & 403,406 \\
\hline $300-399$ & 674 & 701 & 767 & 734 & 802 & 231,822 & 241,263 & 264,313 & 252,700 & 276,519 \\
\hline $400-499$ & 404 & 376 & 408 & 427 & 464 & 179,464 & 167,374 & 182,218 & 190,192 & 206,790 \\
\hline $500-599$ & 255 & 269 & 266 & 270 & 290 & 138,809 & 146,962 & 145,658 & 153,411 & 157,924 \\
\hline $600-699$ & 163 & 166 & 188 & 181 & 181 & 104,528 & 107,419 & 121,414 & 116,482 & 117,080 \\
\hline $700-799$ & 120 & 105 & 137 & 135 & 127 & 89,442 & 78,100 & 102,497 & 105,811 & 95,290 \\
\hline $800-899$ & 86 & 99 & 76 & 88 & 79 & 72,610 & 84,638 & 64,025 & 74,216 & 66,806 \\
\hline $900-999$ & 63 & 57 & 74 & 75 & 74 & 59,231 & 54,195 & 69,820 & 70,987 & 69,947 \\
\hline 1,000 dan lebih/and over & 437 & 414 & 459 & 465 & 517 & $1,185,238$ & $1,091,575$ & $1,247,612$ & $1,288,841$ & $1,384,002$ \\
\hline
\end{tabular}

Source: PERKESO, Department of Statistics Malaysia

\section{Findings}

There were 118 questionnaires distributed and collected to respondent and the researcher received return feedback was 93 respondents. Therefore, our response rate was $78 \%$ considered as low response rate. This is because the situation of COVID 19 hit all over the world including Malaysia. Most of offices and public sector were closed. The researcher had the data collection phase by phase and it is quite difficult to reach the original sample. However, according to Shefali Pandya, 2019, it is preferable to get a high response rate (80\% or higher) from a small, random sample rather than a low response rate from a larger pool of potential respondents. This is consistent with the Australian Vice-chancellors' Committee \& Graduate Careers Council of Australia (2001) regarded 'an overall institutional response rate for the Course Experience Questionnaire (CEQ) of at least $70 \%$ to be both desirable and achievable. This indicates that the response rate for the current study is thus acceptable.

The hypothesis of the study: 
Volume 2 Issue 5 (December 2020) PP. 45-54 DOI 10.35631/AIJBAF.25004

$\mathrm{H}_{0} \quad$ : There is no significant relationship between attitude and tax compliance behaviour

$\mathrm{H}_{1} \quad$ : There is a significant relationship between attitude and tax compliance behaviour

Table 4.5 Nonparametric Correlations between Attitudes and Tax Compliance Behaviour

\begin{tabular}{llr}
\hline & & \multicolumn{1}{c}{$\begin{array}{c}\text { Tax } \\
\text { Compliance } \\
\text { Behaviour } \\
\text { (DV) }\end{array}$} \\
\hline Attitude (IV1) & Pearson & $.561^{* *}$ \\
& Correlation & .000 \\
$* *$. Correlation is significant at the 0.01 level (2-tailed). & 93
\end{tabular}

The findings of the study concluded that, there is a significant positive relationship between attitude and tax compliance behaviour $(\mathrm{r}=0.561, \mathrm{p}=0.000)$. Therefore, $\mathrm{H}_{1}$ is accepted and rejected $\mathrm{H}_{0}$ where there is no relationship between attitude and tax compliance behaviour.

\section{Conclusion}

Based on the findings, the study has indicated that there are a significance and positive relationship between attitude and tax compliance behaviour. This is supported by other studies, for example in Cullis \& Lewis (1997) who found out that attitudes are one of the most important aspect that can influence people to comply to pay tax compliance. They clearly state that compliance with the tax would be comparatively high when there is a favourable attitude towards compliance with the tax. Other than that, another study that supported $\mathrm{t}$ is by Hanno \& Violette (1996). They experientially show a positive correlation between tax compliance attitudes and compliance behaviours. The findings also consistent with Trivedi, Shehata, \& Mestelman, (2005) which also found attitude has significant impact to taxpayers' decisionmaking. In that study, the authors research the role of attitude in both compliance and noncompliance behaviour outcomes and results suggest that attitude is vital in both situations. Next, Elffers, Weigel, \& Hessing, (1987) work also shows a positive relationship with one attitude towards compliance on either side intention to comply. In addition, Kasipillai \& Jabbar, (2003) notes that the attitude towards compliance was statistically important in Malaysia in relation to income reporting behaviours.

As attitudes prove to be able to influence tax compliance, personal perception is important as it will lead to how the way that people will act. If an individual question the attitude of another, people prefer to depend on the person-related views and emotions, an occurrence, a reality, and their behaviours. People's attitudes are the product of the different decisions they make about things, individuals, objects, circumstances, places, and other things. Based on their backgrounds, beliefs, and experiences these may be positive or negative. 
Volume 2 Issue 5 (December 2020) PP. 45-54 DOI 10.35631/AIJBAF.25004

As lot of studies have proven that attitude play a vital role in ensuring people to pay their taxes, the influence of incentives should be taken into consideration. One of the ways that can encourage and give knowledge to the people the importance of tax compliance is by doing a campaign. Everyone is responsible for their own respective taxes. By doing a campaign, awareness among all the citizens can be nurtured.

\section{References}

Abdul Hamid. (2014). Tax compliance behaviour of tax agents : A comparative study of Malaysia and New Zealand. Doctoral Dissertation, University of Canterbury, New Zealand.

Aitken, S. S., \& Bonneville, L. (1980). A general taxpayer opinion survey. Washington: Internal Revenue Service.

Ajzen, I. (1991). The theory of planned behaviour. Organizational Behaviour and Human Decision Processes, 50(2), 179-211.

Alm, J. (1999). Tax compliance and administration. Public Administration and Public Policy. $72,741-768$

Allingham, M. G., \& Sandmo, A. (1972). Income tax evasion: a theoretical analysis. Journal of Public Economics, 1, 323-328.

Andreas Enni Savitri(2015). The effect of tax socialization, tax knowledge, expediency of tax id number and service quality on taxpayers compliance with taxpayers awareness as mediating variables. Proceeding of 2nd Global Conference on Business and Social Science-2015. (pp. 163-169). Bali, Indonesia

Andreoni, J., Erard, B., \& Feinstein, J. (1998). Tax compliance. Journal of Economic Literature, 36(2), 818-860.

Bobek, D. D., \& Hageman, A. M. (2015). The role of client advocacy in the development of tax professionals' advice. Journal of American Taxation Association, 32(1), 25-51.

Chan, C. W., Troutman, C. S., \& O’Bryan, D. (2000). An expanded model of taxpayer compliance: Empirical evidence from the United States and Hong Kong. Journal of International Accounting, Auditing and Taxation, 9(2), 83-103.

Chen, L. E. (2006). Tax knowledge, tax structure and compliance: A report on a quasiexperiment. New Zealand Journal of Taxation Law and Policy, 12(2), 117-140.

Clotfelter, C. T. (1983). Tax evasion and tax rates: An analysis of individual returns. The Review of Economics and Statistics, 65(3), 363-373.

Cohen, L., Manion, L., \& Morrison, K. (2007). Research methods in education. London:Routledge

Cullis, J. G., \& Lewis, A. (1997). Why people pay taxes: From a conventional economic model to a model of social convention. Journal of Economic Psychology, 18, 305-321.

Davis, J. S., Hecht, G., \& Perkins, J. D. (2003). Social behaviors, enforcement and tax compliance dynamics. The Accounting Review, 78(I), 39-69.

Elffers, H., Weigel, R. H., \& Hessing, D. J. (1987). The consequences of different strategies for measuring tax evasion behavior. Journal of Economic Psychology, 8, 311-337.

Eriksen, K., \& Fallan, L. (1996). Tax knowledge and attitudes towards taxation; A report on a quasi-experiment. Journal of Economic Psychology, 17(3), 387-402.

Friedland, N., Maital, S., \& Rutenberg, A. (1978). A simulation study of tax evasion. Journal of Public Economics, 10, 107-116.

Hamzah Sendut.(1991). Managing in a multicultural society: The Malaysian experience. Malaysian Management Review, 26(1), 61-69. 
Volume 2 Issue 5 (December 2020) PP. 45-54 DOI 10.35631/AIJBAF.25004

Hanno, D. M., \& Violette, G. R. (1996). An analysis of moral and social influences on taxpayer behavior. Behavioural Research in Accounting, 8, 57-75.

Hasseldine, J., \& Hite, P. A. (2003). Framing, gender and tax compliance. Journal of Economic Psychology, 24, 517-533.

Hite, P. A. (1997). Identifying and Mitigating Taxpayer Non-compliance, Australia Tax Forum, 156.

Inland Revenue Board of Malaysia. (2019, October 22). LHDN Malaysia. Retrieved from Official Portal Inland Revenue Board of Malaysia: http://lampiran2.hasil.gov.my/pdf/pdfam/annual_report_2017.pdf

Jackson, B., \& Miliron, V. C. (1986). Tax compliance research: Findings, problems, and prospects. Journal of Accounting Literature, 5(1), 125-65.

James, S., \& Alley, C. (2004). Tax Compliance, self assessment and tax administration. Journal of Finance and Management in Public Service, 2(2): 27-42.

Jeyapalan Kasipillai \& Hijattulah Abdul Jaabar (2003). Tax compliance attitude and behaviour: Gender \& ethnicity differences of Malaysian taxpayers. Universiti Utara Malaysia Repository, 1-12.

Kirchler, E., Hoelzl, E., \& Wahl, I. (2008). Enforced versus voluntary tax compliance: The "slippery slope" framework. Journal of Economic Psychology. 29(2), 210-225.

Lindenberg, S., \& Foss, N. J. (2011). Managing joint production motivation: The role of goal framing and governance mechanisms. Academy of Management Review, 36(3), 500525.

OECD Data. (2018, 11 23). OECD Data. Retrieved from OECD.org: https://data.oecd.org/tax/tax-revenue.htm

Orviska, M., \& Hudson, J. (2003). Tax evasion, civic duty and the law abiding citizen. European Journal of Political Economy, 19(1), 83-102.

Park, C.-G., \& Hyun, J. K. (2003). Examining the determinants of tax compliance by experimental data: A case of Korea. Journal of Policy Modeling, 25(8), 673-684.

Pommerehne W.W. (2005). Reasoned action and planned behaviour. In Middle range theories: Application to nursing research, 125-147

Prime Minister's Office of Malaysia. (2019, November 11). Code of Ethics. Retrieved from Prime Minister's Office of Malaysia: https://www.pmo.gov.my/about-us/code-ofethics/

Raihana Mohd Ali \& Pope, J. (2014). The influence of religiosity on taxpayers' compliance attitudes. Accounting Research Journal, 27(1), 71-91. https://doi.org/10.1108/ARJ-08-

Richardson, G. (2006). Determinants of tax evasion: A cross-country investigation. Journal of International Accounting, Auditing and Taxation, 15(2), 150-169.

Richardson, M., \& Sawyer, A. (2001). A taxonomy of the tax compliance literature: Further findings, problems and prospects. Australian Tax Forum, 16, 137-320.

Saad, N. (2011). Fairness Perceptions and Compliance Behaviour: Taxpayers' Judgments in Self-Assessment Environments, Doctor of Philosophy, University of Canterbury, Christchurch.

Song, A. Y., \& Yarbrough, T. E. (1978). Tax Ethics and Taxpayer Attitudes: A Survey. American Society for Public Administration, 38(5), 442-452.

Srinivasan, T. N. (1973). Tax Evasion : A model. Journal of Public Economics, 2(339-346).

Viswanath Umashanker Trivedi, Mohamed Shehata\& Lynn, B. (2003). Impact of personal and situational factors on taxpayer compliance: An experimental analysis. Journal of Business Ethics, 47(3), 175-197. 